\title{
A FUNCTION OF DREAM NARRATIVES IN FAIRY TALES
}

\author{
Judit Gulyás
}

\begin{abstract}
In Hungarian variants of some fairy tale types (especially ATU 315, $707,725)$ the operation of a peculiar dream narrative can be observed: the characters use an embedded dream narrative to communicate information. The agent of knowledge conveys information to a mediating person and in doing so (s)he also governs that when the mediator conveys information to the actual addressee (recipient), the mediator must explain the origin of the conveyed knowledge to the recipient by referring to a fictional dream experience: as if the mediator had had a dream and had gained information in dream. The mediator in these tales always accepts this proposal and when telling the information to the recipient, (s)he conceals the real source of information and substitutes it with a generally available and uncontrollable source of knowledge, as (s)he claims that it has been provided for him/her in a dream. The recipient, having understood the information conveyed in this manner, sets out to perform an action since these sets of information in most cases are about some absent or missing objects or persons, which/whom the recipient should obtain. The article investigates these as if (emphatically fictional) dream narratives and tries to answer a very simple question: why it is necessary (if it is necessary at all) to use these dream narratives in these fairy tales.
\end{abstract}

Key words: dream narratives, fairy tales, morphology

\section{A FUNCTION OF DREAM NARRATIVES IN FAIRY TALES}

The article investigates the function of a special dream narrative observable in fairy tales. ${ }^{1}$ In the Hungarian variants of some fairy tale types (ATU 707, $315,725)$ the operation of a peculiar dream narrative can be observed: the characters purposefully use an embedded, secondary dream narrative to communicate information. I term this special narrative as if dream narrative, because no actual dream experience takes place in these folktales, but, rather, an emphatically fictional dream narrative is applied. According to my presumption, these special dream narratives, taking into consideration their narrative function, belong to the Proppian category of those auxiliary elements that link morphological functions. Propp makes the following remark about these elements: 
We may observe that the functions do not always follow one another directly. If subsequent functions are performed by various characters, then the second character must be informed of what has happened formerly. To bridge these gaps, a whole system of forms providing information operates in fairy tales. Occasionally, forms of information-supply are absent from the tale, in these cases the characters act deus ex machina or they are omniscient; whereas in some other cases, forms providing information emerge when they are not necessary at all. These sets of information link the various functions in course of the realisation of the plot of the tale. ${ }^{2}$ (Propp 1995: 71.)

Propp enlists several equivalent variants of auxiliary elements such as speaking animals, overhearing of a chat, letter, slander, boasting, acoustic and visual information or signs. I am going to argue that as if dream narratives fulfil the same function in some fairy tale types. In accordance with Propp's statements I will focus upon the relationship between these dream narratives and the acquisition, distribution/dissemination and utilisation of information in fairy tales.

The first tale type to be examined from this aspect is ATU 707, The three golden children. The generalised plot of the type is as follows: ${ }^{3}$

Three girls boast that if they marry the king they will fulfil all his wishes. The youngest girl promises that she would give birth to children with golden hair or other magical, extraordinary traits. The king overhears them talking and decides to marry the youngest girl. When the girl gives birth to golden-haired children in the absence of the king, the elder sisters substitute the babies with animals (always with dogs). The mother is imprisoned (banished). Her children are exposed, but ordinary people (gardener, fisherman, etc.) find them, rescue them and bring them up. When they have grown up, they set out to find their parents. The villain recognises the children and she tempts them to carry out difficult, dangerous tasks, because she wants to kill them. The children, with the help of magical helpers, obtain magical objects (persons). These objects draw their father's attention to them. Villainy is revealed, the king recognises his children; their mother is freed, the family is re-united. Finally, the villain is punished. (Dömötör 1988: 395-398; Uther 2004: 381382.)

Although neither the ATU Catalogue, nor The Catalogue of Hungarian Fairy Tales (based on the AaTh catalogue) refer to dream narratives inserted in type 707 , the examination of the Hungarian variants of the type indicates that a 
quarter of these variants applies fictional dream narratives when the existence of magical objects or persons is reported to the children. ${ }^{4}$ The following excerpt from a 20th-century Hungarian variant illustrates the operation of this fictional dream narrative. In this part of the plot, the villain wants to remove the hero, the brother. According to the villain's presumption, performing dangerous tasks would result in the hero's death, whereas the absence of the hero would make it possible for the villain to kill the other child, the sister. Consequently, the king (the source of authority) could not reveal the crime that the villain committed in the past (i.e. that she exchanged the children for dogs). Thus, the iron-nosed witch, the villain herself, visits the protagonist's sister, who is one of the golden-haired children, when she is alone at home, and after a chat she turns to her saying:

'What a jolly good time we would have if your brother brought you three leaves of lilac. Because these leaves of lilac are very nice; they would comfort you, they would play music. But, don't forget, don't tell him that you heard about lilac leaves from anybody. Instead, tell him that you dreamt about them.' The old iron-nosed witch went home. At home she says to her fellow: 'Now, I send the guy to a place where he will perish. He will die there and then I will kill the girl myself; I would kill her, but as long as her brother is alive I can't.' Well, the brother comes home and his sister serves the supper for him. 'Look,' she says, 'my brother, listen what I've dreamt.' 'What?' - he asked her. 'Well, I fell asleep,' she says, 'and I dreamt when I fell asleep. I dreamt that there are three leaves of lilac somewhere, but I can't tell you where exactly in the wide world. But these leaves play the music very finely. And if you brought those leaves home then we would have a jolly good time here, indeed! I wouldn't be so bored here alone.' 'Well, my sister,' he says, 'I will try, do my best and bring you the leaves if I can.' (Ortutay 1978: 119. $)^{5}$

The villain intends to induce action by virtue of transmitting information. To realise her intention and to achieve her purpose, the villain persuades the unsuspecting sister to communicate and mediate the information to the hero with the help of an as if dream narrative. Thus, in these variants the villain chooses an indirect form of information transmission: an emphatically fictional dream narrative. It seems that the main function of dream narratives as information transmitting forms in these fairy tales is that by the application of such dream narratives it becomes possible to conceal the source of information. Behind this strategy an assumption can be detected, according to which access to knowledge via dream is (1) generally available for anybody, and (2) the ob- 
tained information is uncontrollable by other persons. In Hungarian variants when the hero is informed of the existence of magical objects, his response, with regard to the status of information, may be twofold: he either accepts the sister's interpretation on the source of information (like in the above excerpt), or may question it, like in the excerpt below from another Hungarian variant of type 707:

'Look,' she [the villain, an old woman] says, 'my girl, I brought you something to eat, and tell your brother if he comes home that you had a dream and you saw in your dream that he should go and steal Fairy Ilona's horse, because he is a hunter, so it would be proper for him to ride a horse instead of going on foot. And if he asks you from whom you heard about it, tell him that you saw it in your dream, you saw that an old man came to you and he said that your brother should go and steal the horse, because he could steal it. But don't disclose me!' - she says. Because she thought that if she managed to send him there, Fairy Ilona would destroy him there. [---] The boy goes home, by then the old woman left. And the girl says to him what she saw in her dream and that his brother should go and steal Fairy Ilona's horse. Because he is a hunter and it would be proper for him to go on horseback. He says: 'Did anyone instruct you to say so?' She says: 'No, I saw it in my dream.' Well then, next morning he set out. He set out to find Fairy Ilona. (Dégh 1960: 7879.)

Regardless of the hero's immediate reaction, i.e. whether the hero accepts or questions the source of information (which response, acceptance or scepticism, is morphologically irrelevant as only actions constitute the functions and, thus, the plot of the narrative), in each variant the hero eventually always follows the instructions conveyed by the as if dream narratives and sets out to seize the magical objects. Therefore both the sister as well as the brother unintentionally obey the villain and, at the same time, Propp's rule, which says: "The hero always violates interdictions, whereas he always accepts and performs deceptive and destructive proposals." (Propp 1995: 37.) This is quite an important observation, since it is precisely this behaviour of the hero that, among other constituents, ensures the dynamics of the narrative. If there is no action, there is no tale, as action is the fundamental structural element of a fairy tale. When in another tale type the princess sends her father to fetch her the problematically available magical fruits, this request, taking into consideration its consequences, fulfils the same narrative function as the narrative solution in variants of type 707 when the sister sends her brother to fetch her leaves of magical lilac as a difficult task. However, in the first case the request 
(as a difficult task) is conveyed directly, whereas in the above quoted variants of type 707 it is wrapped in a dream narrative form, since in this way the real source of information and the existence of the real agent of request can be concealed.

I term these types of dream narratives as if dream narratives, in which the dream experience is actually non-existent. The form of a dream narrative is assigned to information as a verifying form of communication in order to conceal the source of information. Such an as if dream narrative needs three characters or roles, which I am going to name as the agent, the mediator and the recipient of information. The agent is the real source of the information to be conveyed by the mediator for the recipient (in the tales above it is the ironnosed witch / old woman). The mediator is the fictional dreamer who conveys knowledge to recipient as if (s)he $\mathrm{e}^{6}$ had gained access to it in his/her dream (in the tales above this role is played by the sister). The recipient is the character who carries out action relying upon the information gained by the mediator (in the tales above the recipient is the brother, i.e. the hero).

The emergence of fictional dream narratives can also be observed in the Hungarian variants of two other fairy tale types: ATU 315 and 725 . The generalised plot of type 315 (The faithless sister) is as follows:

Brother and sister/son and mother leave home (are driven out). The brother/son kills a number of robbers but does not realise that the last one is merely wounded. The sister/mother helps the wounded robber to recover, and he becomes her secret lover. In order to get rid of the brother/ son, she pretends to be ill and sends him out to get her the milk (liver) of dangerous animals. The brother spares the animals (whelps) and they follow him. Then his sister/mother with the help of her lover wants to kill the hero at home. She asks him to complete dangerous tasks. The animals save the hero and he punishes both his sister/mother and her lover. (Dömötör 1988: 117-121; Uther 2004: 201-202.) ${ }^{7}$

The utilisation of fictional dream experiences is most frequently related to the malevolent wish-fulfilment scene. Excerpts from two Hungarian variants:

And then the robber and his [the hero's] sister were very much frightened when they saw that they couldn't kill him. The robber had an idea again. The girl should pretend that she had a dream and she should scream. She said that she was fatally ill, but if her brother brought her three golden pears then she would recover. And her brother went again 
to a garden. All the bears that live in the wide world were there. (Horger 1908: 51.)

The boy comes home. His mother pretends to be ill, terminally ill. The boy asks her: 'Well, what's the matter, my dear sweet mother?' 'I had a dream, my dear sweet son, that if you get off your clothes and you sit into the tub naked so that I could wash your hands and legs then I would recover.' (Géczi 1989: 318.) ${ }^{8}$

Setting the difficult (and dangerous) tasks for the hero may take place from various argumentative positions: the mother/sister either refers to her pretended illness or to her pretended dream experience. The application of these solutions may vary in the variants: either each difficult task is related to fictional illness or dream experience or these two arguments are combined.

A major difference between the application of fictional dream narratives in Hungarian variants of ATU tale types 707 and 315 is related to the dissemination of information among various characters, which determines their interpretive positions with regard to the information to be transmitted. In the variants of type 707, the character who mediates the difficult task to the hero is unaware of the destructive intention underlying the agent's wish. Neither the mediator, nor the recipient is aware of the existence of a villain, therefore they cannot identify the agent with a villain's usual and hostile intentions, purposes and actions. In contrast, in the variants of type 315 , when the mediator sets the difficult task to the hero, she is well aware of its implications. In the variants of type 315 the participation of the mediator is a necessary prerequisite, because in these tales (as opposed to type 707) the hero knows the villain and is in a hostile relationship with him, although he believes him to be dead and does not know about his actual presence. The introduction of a mediator character in these tales is necessary to conceal the agent's (the villain's) presence and identity. Altogether, in type 707 it is not compulsory but optional to hide the identity/existence of the agent of the knowledge (the villain), but in those variants where the agent of information is hidden from the recipient (the hero) the only applied narrative technique is as if dream narrative; whereas in type 315 it is by all means compulsory to hide the identity /existence of the agent of knowledge (the villain) from the recipient (the hero), but it can be performed with various narrative solutions, among which as if dream narratives may also emerge.

As far as the correlation between the narrative roles of as if dream narratives and the Proppian morphological roles are concerned: the source of information, the agent, in these two tale types is the villain, the mediator bears 
some traits of the Proppian role of tsarina/princess as it is she who actually sets the difficult task for the hero, whereas the recipient of the information is the hero.

This correlation does not necessarily emerge in all tale types that apply fictional dream narratives. In another tale type, (ATU 725, Prophecy of Future Sovereignty) the relationship between narrative and morphological roles is different, since in this case it is the hero who is the agent of the knowledge and whose presence and identity should be concealed by the application of serial, inserted as if dream narratives. The summary of the plot is as follows:

A clever, poor boy refuses to tell his dream (about his future sovereignty) to his father and to the king. He is sentenced to death (imprisonment, walling in). The princess nourishes him secretly in prison. (Not knowing about it, the king believes that the boy is already dead.) War is to be declared on the emperor if he is not able to solve various riddles and tasks. The walled-up boy solves the riddles and the tasks, tells the answers to the princess, who reports the solutions to her father. The boy is eventually freed from prison. So the boy averts war, marries the princess, and finally receives two kingdoms. (Dömötör 1988: 409-412; Uther 2004: 390.$)^{9}$

In these variants dream narratives may be inserted into three various parts of the plot: (1) in the initial phase, where, quite paradoxically, the absence of a dream narrative (as a basic conflict) is related; (2) in course of performing difficult tasks (if in this part of the plot a dream narrative is inserted, it is always a fictional one, whose agent is the hero, the mediator is the princess and the recipient is the king); and, finally, (3) the closure of the tale may also contain a (fictional) dream narrative:

[The boy to the princess:] "Now, go home and at once lie in bed, and by now your father believes in everything that you say, so when you lie down you should wake up suddenly and when your father asks you: "what have you dreamt, my child?" then you should say that you had a strange dream because the only person who could carry out this task is not alive any longer - perhaps." (Béres 1967: 218.)

These secondary dream narratives are all assigned to the hero in these tales. The embedding of the first dream narrative (which dream narrative is actually marked by a gap in narration) into the tale implies such a basic interpretation (generally observable in fairy tales) according to which dream experiences include relevant information (which, thus, cannot be neglected) and that access to knowledge revealed in dream experience may be possible only via the nar- 
ration of dream experience. The specific features of knowledge gained by dream (I will name it dream knowledge) are as follows: (1) in principle anyone could have access to it, (2) but access cannot be volitional; revealing knowledge via dream is accidental; (3) knowledge revealed by dream is available in each case for only one person, i.e. the actual dreamer of the dream. Therefore knowledge gained by dream is available for a community only via a dream narrative. Let me refer, at this point, to the fact that other modes of information transmission in fairy tales are not necessarily restricted to one recipient, for instance, the knowledge possessed by donors or helpers just as well as the information encoded in signs can be disclosed to a number of characters. (For instance, if the first brother dies while performing a difficult task, the information necessary for the accomplishment of the task can be provided for the second hero too, for example, the magical horse may report the necessary information to him or he may find the same telling signs on his way just as well as his brother found it, etc).

As knowledge derived from dream experience is assigned to and possessed by only one character, it is quite logical that the community (whose chief representative, in this case, is the king), which considers this knowledge relevant, makes repeated efforts to get access to it. ${ }^{10}$ The denial of the narration of the content of the dream, or, rather, the element that although the hero communicates the existence and relevance of his dream experience and dream knowledge, but he does not reveal its actual content, gains an interpretation that is set in the framework of power relations in this tale type. Silence makes the hero exposed but it also vests him with some authority as he is uncontrollable. This is obvious for both the hero (the dreamer) and the community. The representative of the community applies sanctions against the hero endowed with uncontrollable knowledge and tries to exercise control over him by virtue of, at least, his spatial isolation.

The application of as if dream narratives in these tales creates a peculiar metanarrative situation. The frame narrative of the tale focuses on the use and share of, access to and control of knowledge gained by dream experience, therefore it seems to be some metanarrative ironic turn that the hero, who is condemned to segregation by (the representative of) the community precisely because of his dream knowledge, returns to the community by assigning a dream narrative form to his knowledge and he shares it (with the help of a mediating person) with the penalizing authority. At the same time, at the level of the narrative itself, it is a logical and adequate narrative solution to assign such a form to the hero's knowledge as it may conceal the hero's presence and identity from the narrative audience, i.e. from the community that penalized and segregated him. The primary function of as if dream narratives, as we 
have seen above, is that it makes information agentless. At the end of the tale a special narrative situation is created: the agent of the knowledge communicates such information via the mediator to the representative of the community that is agent-concealing in form, while at the same time it claims the presence of the agent and his control of knowledge in content (cf. excerpt above).

Examining the structure and context of $a$ s if dream narratives inserted in the above presented three tale types, it can be observed that the element of explicit interpretation of the narrated dream is almost completely absent (with the exception of subsequent action, which is, of course, a consequence of the information conveyed by dream, therefore the performed action is implicitly an interpretation/evaluation of the information obtained). Revealing information in these dream narratives takes place directly; the information is not symbolically-metaphorically encoded. Symbolic-metaphoric coding of dream experiences of the characters is a well-known phenomenon in other narrative genres, e. g. in folk ballads. ${ }^{11}$

In contrast, because as if dream narratives of folktales lack coding, therefore decoding, i.e. explicit dream interpretation is not required in the text. Knowledge transmitted via as if dream narratives functions as a sort of operating manual. First, the dream narrative states the existence of something or somebody, then it can be accompanied by supplementing argumentation whose aim is to reinforce the establishment of the sense of lack/absence for the recipient, which is finally followed by the recipient's action: ( $\mathrm{s}$ )he sets out to seize the missing object/person and, basically, to enter a series of other actions as well. The embedded as if dream narrative is integrated into the frame narrative by the recipient's action, as the narrative purpose of information transmission and distribution among characters of fairy tales is to ensure the progress and dynamics of the plot.

\section{ACKNOWLEDGEMENTS}

The article was prepared with the support of Folklore Text Analysis Research Group of the Hungarian Academy of Sciences and Eötvös Loránd University (MTA FSZKCS). 


\section{COMMENTS}

${ }^{1}$ In the article the terms fairy tale and folktale denote 'tales of magic' (ATU 300-749).

${ }^{2}$ My own translation from the standard Hungarian translation of Морфология сказкии.

${ }^{3}$ I used basically the Aarne-Thompson-Uther sujet descriptions in each case, but as I intend to present the characteristic, shared features of Hungarian variants, I also used The Catalogue of Hungarian Fairy Tales (published in 1988, relying on AaTh Catalogue), and combined the plot descriptions of these two catalogues.

${ }^{4}$ The Catalogue of Hungarian Fairy Tales (accepted abbreviation: MNK2) registers 35 variants of the type, out of which 28 represent the type in itself, the rest of them is a combination of types. The earliest variant is from 1822, the latest one is from 1970.

${ }^{5}$ All excerpts from Hungarian tales quoted in the article are my own translations. This tale was related by a most prominent Hungarian tale-teller, Mihály Fedics, in northeastern Hungary; the text was recorded by Gyula Ortutay and was published for the first time in 1940.

${ }^{6}$ As a matter of fact, in all Hungarian variants of the three tale types under survey the mediator is always a woman. It is the gender of the agent and the recipient that may vary.

7 The Catalogue of Hungarian Fairy Tales registers 50 variants of the type, out of which 8 represent the type in itself, the rest of them is a combination of types. The earliest variant is from the middle of the 19 th century (manuscript variant), the latest one is from 1979.

8 This variant is not enlisted in The Catalogue of Hungarian Fairy Tales as it was published a year later than the catalogue had been issued. Perhaps it is not really self-evident why the bathing scene implies a difficult and dangerous task. Fulfilling his mother's wish, the boy sits into the tub naked and his mother and the villain try to kill him in the tub. Water emerges as a dangerous medium in several fairy tales. Crossing brooks, rivers, lakes or seas is often problematic for the hero (who can perform the task only with a magical helper), and submerging into water may bring about the hero's loss of self-control (as a sort of altered state of consciousness in this case), which makes it possible for the villain to commit counter-action. Therefore inducing the hero's loss of control (of himself and of his environment) is a narrative strategy to ensure the dynamics of the plot. (A fully competent and omniscient hero would not make it possible for the narrator to apply conflicts and absence/lack that are necessary preconditions for the introduction of actions.) In several Hungarian folk ballads and fairy tales a functionally equivalent narrative technique is when the hero falls asleep (whereas, functionally, falling asleep and having a dream experience are by no means equivalent, as the former solution ensures the transitional absence of the character and the active presence of the villain, while the latter solution primarily provides information for the characters of the tale).

9 The Catalogue of Hungarian Fairy Tales assigns two basic tale types to this sujet (MNK 725, The Dream, and MNK 725A ${ }^{\mathrm{x}}$ The Clever Boy $=$ AaTh 725+AaTh 625) and registers altogether $3(\mathrm{MNK} 725)$ and $22\left(\mathrm{MNK} 725 \mathrm{~A}^{\mathrm{x}}\right)$ variants. The earliest Hungarian variant is from 1846, the latest one was recorded between 1966-1970. 
${ }^{10} \mathrm{Cf}$. Veronika Görög's article on the relationship between dream-knowledge and censorship (Görög 1999: 353-357).

11 An excerpt from a folk ballad on the mother who killed her child (the variant was recorded in 1972) as an example of metaphoric coding and the accompanying explicit interpretation:

My mother, my sweet mother,

I had a dream,

Two black ravens

Were above my head.

They held with their clutches

Silk cords,

They held with their clutches

Silk cords.

My daughter, my sweet daughter,

Two black ravens,

Two black ravens

Are your judges.
Silk cords

Are ropes for you,

Silk cords

Are ropes for you.

My mother, my sweet mother,

Mourn over me,

Mourn over me,

As long as you can see me.

(Kallós 1996: 110.)

\section{REFERENCES}

Béres, András 1967. Rozsályi népmesék [The Folktales of Rozsály]. Budapest: Akadémiai Kiadó.

Dégh, Linda 1960. Kakasdi népmesék II [The Folktales of Kakasd. II]. Budapest: Akadémiai Kiadó.

Dömötör, Ákos 1988. A magyar tündérmesék típusai. [The types of Hungarian fairy tales]. Budapest: Institute of Ethnology of HAS. (The Catalogue of Hungarian Folktales 2./MNK 2.)

Géczi, Lajos 1989. Ungi népmesék és mondák. [Folktales and legends from Ung] Budapest: Akadémiai Kiadó.

Görög, Veronika 1999. Predesztináció és álom a mesében. [Predestination and Dream in Tales] Benedek, Katalin \& Csonka-Takács, Eszter (eds.) 1999. Démonikus és szakrális világok határán. Mentalitástörténeti tanulmányok Pócs Éva 60. születésnapjára. [At the Borderline of Demonic and Sacral Worlds. Studies in the History of Mentality for the 60th Birthday of Éva Pócs]. Budapest: Institute of Ethnology of HAS, pp. 147162.

Horger, Antal 1908. Hétfalusi csángó népmesék [The Csángó Folktales of Hétfalu]. Budapest: Kisfaludy Társaság-Athenaeum.

Kallós, Zoltán 1996. Ez az utazólevelem. Balladák új könyve [This is My Passport. New Book of Ballads]. Budapest: Akadémiai Kiadó. 
Ortutay, Gyula 1978. Fedics Mihály mesél [Mihály Fedics Tells Stories]. Budapest: Akadémiai.

Propp, Vladimir J. 1995. A mese morfológiája [The Morphology of Tale]. Budapest: Osiris.

Uther, Hans-Jörg 2004. The types of international folktales. A classification and bibliography. Part I. FF Communication 284. Helsinki: Suomalainen Tiedeakatemia. 